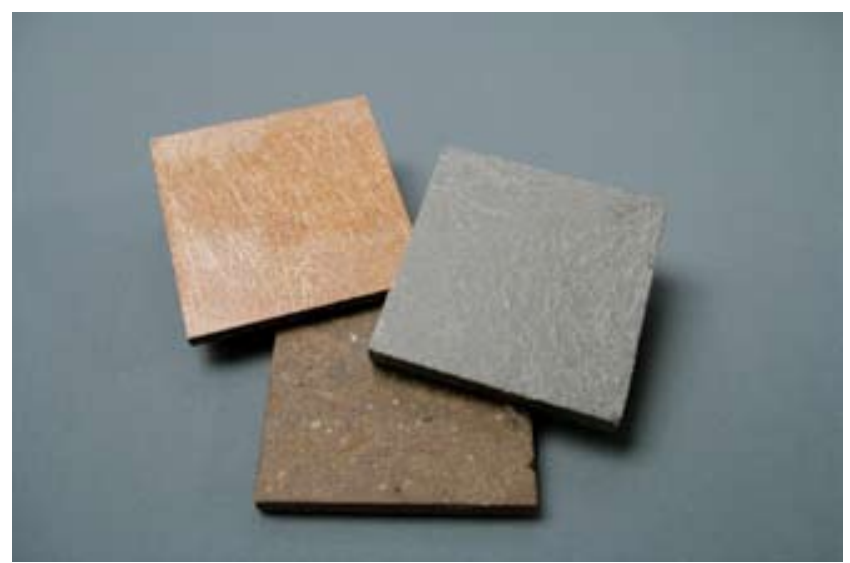

Figure 1. Domestic wasteboard made mostly of unsegregated rubbish.

building materials are being investigated and brought into the construction marketplace with renewed vigor. Hemp, straw, sisal, and jute are being used as fiber reinforcements or fillers for composite products (where limecrete, epoxy, phenolics, or formaldehyde-based binders are used) and blocks. The manufacturing of films and polymers from starch is also in development, as is the production of adhesive systems based on tannins. Whether these types of materials ever make it into the mainstream remains to be seen, but their use in more niche buildings will inevitably grow.

\section{Phase Change Materials}

The entropy changes associated with the transformation of a material from one phase to another can be exploited as a temperature-controlling mechanism in buildings. DuPont has pio- neered this approach with their Energain product. The phase change material is sandwiched between two thin aluminum foils, and at around $22^{\circ} \mathrm{C}$, it goes through a phase change. In doing so, the material absorbs heat from the atmosphere. In a room internally wrapped in this product, this behavior helps to mitigate heat buildup, thereby helping to keep the room cool without the need for air conditioning. The use of phase change materials is very likely to increase in construction and other applications such as transport.

\section{Summary}

It is clear that environmental sustainability is driving change throughout the construction sector in a manner that has not been seen for many decades. A key to reducing environmental impacts lies in the materials and products that are used in our buildings - in reducing their environmental impacts through manufacturing and use - and in designing them into buildings that are significantly more environmentally efficient. This endeavor provides a new sense of purpose and a new energy to materials scientists and technologists who have much to offer and much to do to enable delivery of the innovation required.

\section{References}

1. The European Parliament and The Council of the European Union, On the Energy Performance of Buildings (Directive 2002/91/Ec, December 16, 2002; www.diag.org.uk/media/18832/epd_final.pdf) (accessed January 2008).

2. Building Research Establishment, BRE's Environmental Profiles (BRE, Watford, UK; www.bre.co.uk/page.jsp?id=53) (accessed January 2008).

3. Building Research Establishment, The BRE Green Guide to Specification (BRE, Watford, UK; www.bre.co.uk/greenguide/page.jsp?id=499) (accessed January 2008).

4. Building Research Establishment, BREEAM: BREEnvironmental Assessment Method (BRE, Watford, UK; www.breeam.org) (accessed January 2008).

5. Building Research Establishment, BRE: The Code for Sustainable Homes (BRE, Watford, UK; www.bre.co.uk/page.jsp?id=847) (accessed January 2008).

\title{
A Super-Green Factory: The Sharp Kameyama Plant
}

\author{
Tetsuo Kusakabe (Sharp Corporation, Japan)
}

\section{Integrating Different Types of Large-Scale Power Sources into a Distributed Power Supply System}

Sharp Corporation is making a concerted effort to reduce environmental impacts to the greatest extent possible at its production facilities around the world, and it is applying its own original evaluation criteria to recognize those plants having an extremely high level of environmental performance as "SuperGreen Factories."

Our Kameyama plant, the first such factory to be so recognized, is an integrated, start-to-finish production facility for liquid-crystal display (LCD) televisions (TVs), from fabricating the LCD panel to assembling the finished TV set (see Table I). Given that large amounts of energy are consumed to operate production equipment and to power air conditioning, we focused particular attention on environmental measures intended to reduce global warming and introduced an energy supply system that combines environmental friendliness and operational stability. ${ }^{2}$ As shown in Figure 1, this system is based on integrating different types of large-scale distributed power sources and consists of a gas-fired cogeneration system, a fuel cell system, and a photovoltaic power generating system. The power output of this system covers about one-third of the total electrical needs of the plant.

By situating the equipment that makes up this distributed power supply at the point where demand occurs, we are able to reduce power transmission losses compared to power supplied from distant generating stations, and we can effectively utilize the waste heat created at the time the electricity is generated, enabling the energy to be used efficiently. This approach also 
has the advantage of leveling out power demand by increasing or decreasing power generation in accordance with demand fluctuations within the plant. Moreover, under a photovoltaic

Table I: Sharp Kameyama Plant.

\begin{tabular}{|c|c|}
\hline Site area & Approximately $330,000 \mathrm{~m}^{2}$ \\
\hline Number of workers & 1,850 (as of April 1, 2007) \\
\hline \multicolumn{2}{|c|}{ Kameyama Plant No. 1} \\
\hline \multicolumn{2}{|l|}{ Large LCD plant } \\
\hline Total floor area & Approximately $130,000 \mathrm{~m}^{2}$ \\
\hline Glass substrate size & $\begin{array}{l}\text { Sixth-generation } 1500 \times 1800 \mathrm{~mm} \\
\text { [eight } 32-\text { in. }(81-\mathrm{cm}) \text { panels or } \\
\text { six } 37-\text {-in. }(94-\mathrm{cm}) \text { panels per } \\
\text { substrate] }\end{array}$ \\
\hline Substrate input & 60,000 panels per month \\
\hline \multicolumn{2}{|l|}{ Large LCD TV plant } \\
\hline Total floor area & Approximately $77,600 \mathrm{~m}^{2}$ \\
\hline Production items & $\begin{array}{l}\text { LCD TVs, } 26 \text { in. }(66 \mathrm{~cm}) \text { or } \\
\text { larger }\end{array}$ \\
\hline Production capacity & 100,000 units per month \\
\hline \multicolumn{2}{|c|}{ Kameyama Plant No. 2} \\
\hline Total floor area & Approximately $279,100 \mathrm{~m}^{2}$ \\
\hline Glass substrate size & $\begin{array}{l}\text { Eighth-generation } 2160 \times 2460 \\
\text { mm [eight } 40 \text {-in. }(102-\mathrm{cm}) \\
\text { panels or six } 50 \text {-in. }(127-\mathrm{cm}) \\
\text { panels per substrate] }\end{array}$ \\
\hline Substrate input & 30,000 panels per month \\
\hline
\end{tabular}

power system, peak generating hours correspond precisely with the hours of peak electricity demand, thereby reducing the amount of power that must be supplied by power companies and making this distributed power supply system an effective means of reducing power costs.

Furthermore, because an independent source of power is available from within the site, even when power from the utility grid is interrupted as a result of lightning strikes or other anomalies, we can still ensure stable, continuous operation of the plant without halting production, thus minimizing opportunity losses resulting from operational interruptions.

In addition to the power generating equipment mentioned, we also installed a high-efficiency electrical power storage system at the Kameyama plant to compensate for voltage sags. It comprises a superconducting magnetic energy storage system in which $\mathrm{NbTi}$ (niobium titanium) Rutherford cables are used along with an electric double-layer capacitor energy storage system.

The introduction of such a distributed power supply system reduces $\mathrm{CO}_{2}$ emissions resulting from energy consumption at the Kameyama plant by about 82,000 tons of $\mathrm{CO}_{2}$ per year compared to conventional thermal power generation.

\section{Problems of Distributed Power Supply \\ Equipment and Expectations for the Future}

When we introduced this distributed power supply equipment, we took a proactive approach in adopting new technologies. One of these is the fuel cell. At this plant, we adopted a molten carbonate fuel cell that allows us to make use of the waste heat generated during its operation.

The outstanding feature of fuel cells is their high electrical generating efficiency. Also, because they burn no fuel, they generate almost no air pollutants such as NOx or SOx. The hydrogen needed by the cell to generate electricity is obtained by reforming ("cracking") city gas (liquid natural gas, or LNG), but if we had a system to generate biogas by recycling waste products from within the site, we could build a closed-loop system that would enable us to get the benefit of the energy in a seamless manner. We are currently considering undertaking a joint research program with a university on collecting methane by decomposing highly concentrated organic waste fluids at the plant.

Thus, fuel cells offer many advantages from an environmental standpoint, but because they are a new technology, they also present numerous problems, particularly on the reliability side. Among these are extending the service life of the cell stack, the main component of the system, and improving the reliability of the materials used in the stack. Cost is yet another obstacle to broadening the use of fuel cells. Specifically, both the cost of the materials that make up a fuel cell and the cost of fuel cell production need to be lowered.
Figure 1. Energy supply system based on integrating
the Kameyama plant. Note: LNG, liquid natural gas.

LNG pipeline (total length of $17 \mathrm{~km}$ from Suzuka City to Kameyama City) 
Next is the photovoltaic (PV) power generating system. At the Kameyama plant, we installed thin-film "see-through" solar cells, a new technology, on the curtain walls of the plant buildings (Figure 2). During the day, they generate electricity while allowing light to pass through. They also have a moderate shading effect that cuts heat gain from solar radiation, making it possible to reduce the electric power load from air conditioning. These thinfilm solar cells use a compound semiconductor in addition to a silicon-based material. However, because thin-film solar cells have a lower module conversion efficiency rate than crystalline solar cells, improving conversion efficiency is one of the problems that must be solved.

Solar cells also need a large installation area, and this is a disadvantage. Nevertheless, for thin-film solar cells, we can expect applications to grow, through approaches such as mounting them on the window surfaces of high-rise buildings in urban centers where installing ordinary solar cells on a large scale would be problematic. Thus, we look forward to the benefits of improved conversion efficiency resulting from diversification in materials and improvements in solar cell architectures.

$\mathrm{CO}_{2}$ emissions increase as business expands. Reducing these emissions as much as possible is one of the pressing issues facing Sharp. It is important for us to develop a manufacturing process that uses as little power as possible but that is also highly productive. In addition, for further reductions in $\mathrm{CO}_{2}$ emissions, we anticipate the development of a technology to collect $\mathrm{CO}_{2}$ emitted from burning fuel.

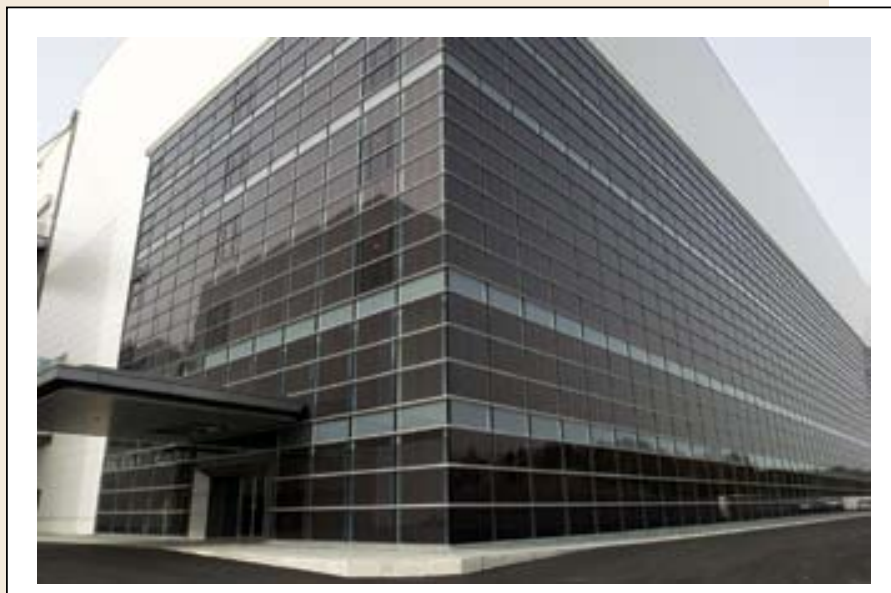

Figure 2. Thin-film "see-through" solar cells covering the windows of an office building.

\section{References}

1. Sharp Environmental and Social Report (Sharp Corporation, Osaka, Japan, 2006); http://sharp-world.com/corporate/eco/csr_report/pdf2006.html (accessed January 2008).

2. A.B. Lovins, E.K. Datta, T. Feiler, K.R. Rábago, J.N. Swisher, A. Lehmann, K. Wicker, Small Is Profitable: The Hidden Economic Benefits of Making Electrical Resources the Right Size (Earthscan, London, 2002).

\section{JA N I S}

\section{CRYOGENICS FROM JANIS}

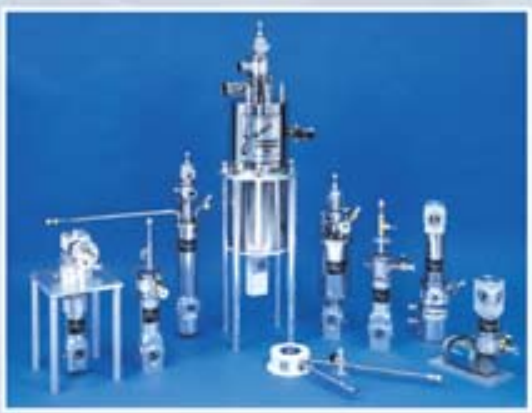

- $10 \mathrm{mK}$ to $800 \mathrm{~K}$

- Cryocoolers

- LHe/L $\mathrm{N}_{2}$ Cryostats

- Magnet Systems

- Dilution Refrigerator Systems

- Micromanipulated Probe Stations

Janis Research Company

2 Jewel Drive Wilmington, $M A$ O 01887 USA

TEL +1 $978657-8750$ FAX $+1978658-0349$ salesejanis.com Visit our website at WWW.janis.com.

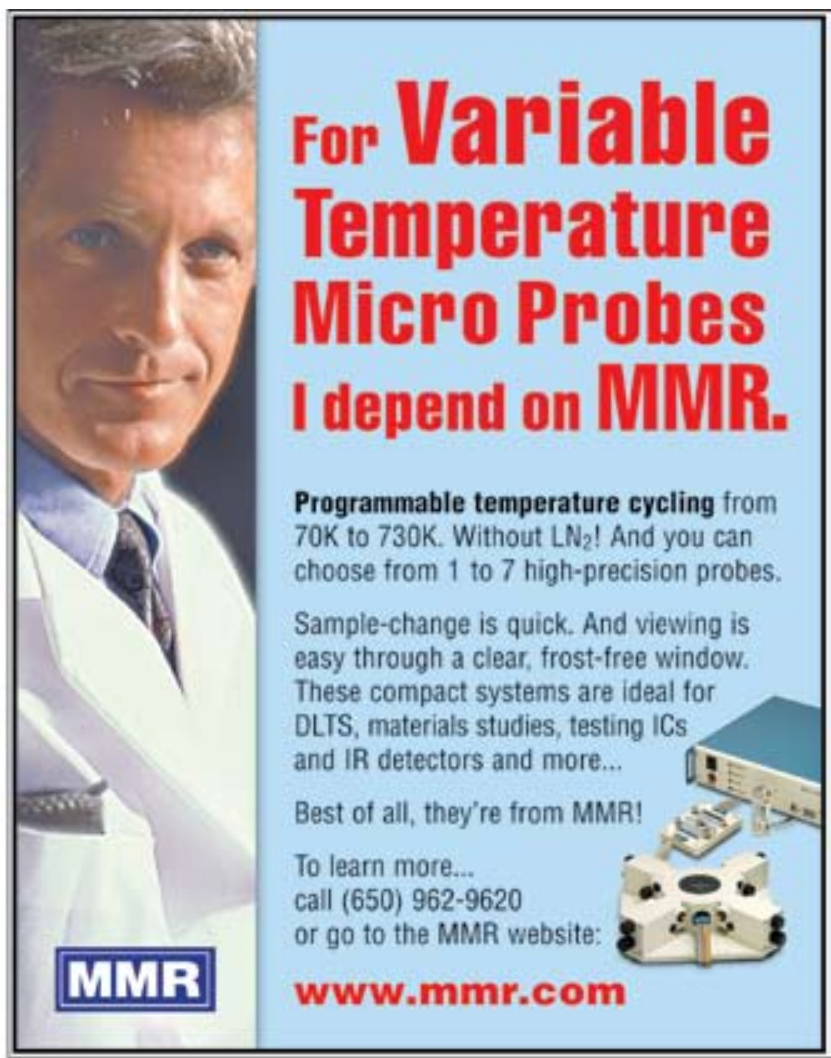




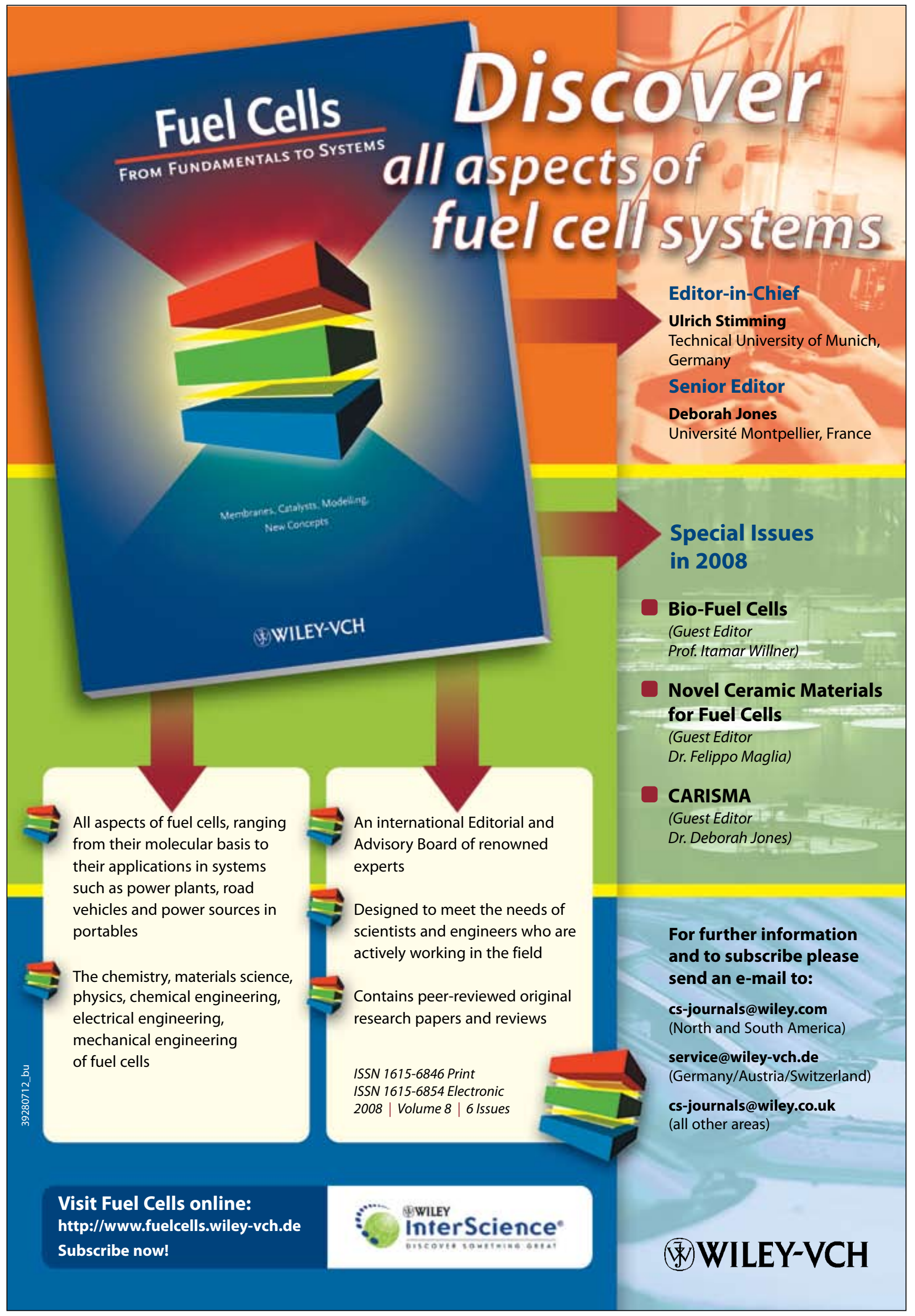

